\title{
The Effect of Quality of Life Work on Organizational Commitment: A Comparative Analysis on School Administrators and Teachers
}

\author{
Mustafa Özgenel, Istanbul Sabahattin Zaim University, Faculty of Education, mustafa.ozgenel@izu.edu.tr, \\ ORCID: 0000-0002-7276-4865
}

\begin{abstract}
Quality of life work (QWL) attracts the attention of both employers and researchers in order to increase the organizational commitment and performance of employees. In this sense, the aim of this study is to compare the effect of the perception of the quality of work-life on the organizational commitment of the administrators and teachers. The research was designed according to the predictive correlation pattern which is one of the quantitative research designs. In the 2018-2019 and 2019-220 academic year, 782 educators, 591 teachers and 191 administrators working in public schools in Tuzla and Sultanbeyli districts participated in the study. In this study, data were collected using the Quality of Life Scale and Organizational Commitment Scale, and t-test, correlation and regression analyzes were performed. According to the results of the analysis, administrators' perceptions of quality of work-life and organizational commitment are higher than teachers. The relationship between administrators' perception of the quality of work-life and organizational commitment levels is lower than the relationship between teachers' perception of the quality of work-life and organizational commitment levels. According to the regression analysis, the quality of work-life predicts $52 \%$ of teachers' organizational commitment and 33\% of administrators' organizational commitment.
\end{abstract}

Keywords: Work-life, quality of work, quality of work-life, organizational commitments

$\begin{array}{lll}\text { Received:04.12.2019 Accepted:18.07.2020 } & \text { Published: 15.01.2021 }\end{array}$

\section{INTRODUCTION}

Since the beginning of the 19th century, with industrialization, organizations have made many innovations in the workplace and management and tried to adapt to the changes to improve themselves, to compete, to improve their efficiency and effectiveness. Variables such as organizational communication, organizational commitment, work stress, and work performance have received great interest in organizational behavior research. Because these organizational variables are considered profoundly important for the overall performance of an organization (Chen, Silverthorne, \& Hung, 2006). In this regard, there is a need to examine the employees' commitment to the organization and the factors affecting their commitment (Cohen, 2007). The concept of Quality of Work Life [OWL], which aims to establish a healthy working environment for organizations to use human resources efficiently, to ensure employees receive satisfaction from their jobs and to feel comfortable and safe, has been brought to the agenda (Akar \& Üstüner, 2017). After the 1950s, the OWL entered the management literature and began research (Subburethina Bharathi, Umaselvi, \& Senthil Kumar, 2010; Gayathiri \& Ramakrishnan, 2013; Gibson, Ivancevich, Donnelly, \& Konopaske, 1991). This concept is a broad concept that expresses many aspects of work ethics and working conditions (Aba, 2009; Easton \& Van Laar, 2013).

The concept of quality work of life represents a multidimensional structure that attaches importance to the human being from the system that regards human as machine and emphasizes the relationship between the employee and the workspace and environment (Akar \& Üstüner, 2017; Erdem, 2010; Saraji \& Dargahi, 2006). Researchers have proposed various definitions by emphasizing workplace issues and conditions and highlighting factors such as psychological wellbeing or happiness and life satisfaction (Easton \& Van Laar, 2018). According to Davis (1997), quality of work-life is the degree of satisfaction of employees in relation to important personal 
needs and organizational needs (Dehghan Nayeri, Salehi, \& Ali Asadi Noghabi, 2011). Nadler and Lawler (1983) describe the quality of work-life as a way of approach that includes employees, the work itself, and the organizations. The most prominent feature of the quality of work-life is it affects both employees and organizational processes. Danna and Griffin (1999), on the other hand, define the quality of work-life as the satisfaction that covers factors like life satisfaction, job satisfaction, and wage. Quality of work-life (QWL) defined as an activity occurring at all levels of an organization (Kaur, 2016) through a management philosophy that enhances employee dignity, promotes cultural change, provides opportunities for growth and development (Gibson, Ivancevich, Donnelly, \& Konopaske, 1991) and seeking more organizational effectiveness increased human dignity and growth. Put differently, quality of work-life refers to the relationship between an employee and the work environment with social, technical and economic dimensions (Gayathiri \& Ramakrishnan, 2013).

QWL can be evaluated as a combination of job satisfaction, participation, motivation, and the balance between work and other aspects of a person's life (Shobe, 1983), the degree of attractiveness of the organization to the employee, as it aims at improving the effectiveness of the organization and the improvement in the work-life of employees (Aba, 2009) or working comfort. However, the quality of work-life is not only the physical opportunities offered to the employee. It would be a lack of perspective to discern the quality of work as the quality of the physical environment only (Dolan \& Lingham, 2012). Quality of work life, work security, good working conditions, adequate and fair compensation, and equal employment opportunity attract new talent to the organization and ensure that existing talent remains in the organization. Employees work for salaries. However, employees continue to work as long as their working conditions are attractive and satisfying (Kaur, 2016).

Different researchers divide the quality of work-life into different behavioral dimensions (Van Laar, Edwards, \& Easton, 2007). It should be noted that pioneering studies have been conducted by Walton (1973), Hackman and Oldham (1975), Westley (1979), Werther and Davis (1983) and Nadler and Lawler (1983) (Fernandes, Martins, Caixeta, \& Antonialli, 2017). Walton (1975) described eight dimensions of QWL. These; (i) adequate and fair payment, (ii) safe and healthy working conditions, (iii) opportunity to develop human capacities, (iv) opportunity to growth and security, (v) social cohesion in the organization, (vi) structure of the organization, (vii) work and total living space, (viii) social appropriateness of working life (as cited in Fernandes, Martins, Caixeta, \& Antonialli, 2017).

Although there are difficulties in the conceptualization, measurement, and comparison of variables in studies on organizational behavior or organizational structures (Walton, 1981), studies have been conducted to measure the quality of work life and various models have been put forward. Van Laar, Edwards and Easton (2007) divided the quality of work life into measurable behavioral dimensions and tried to measure accordingly. The quality of work life scale, developed by Van Laar, Edwards and Easton (2007) to measure the quality of work life of healthcare workers, consists of 6 behavioral dimensions. Dimensions of the scale; (i) job and career satisfaction, (ii) general well-being, (iii) control at work, (iv) stress at work, (v) working conditions; and (vi) home-work interface. Sirgy, Efraty, Siegel, and Lee (2001) conducted three separate studies in an accounting company and two universities and gathered quality of work in seven sub-dimensions. These; (i) health and safety (protection from severe health and injury at work and outside work and promotion of good health), (ii) economic and family needs (safety and other family needs), (iii) social needs (workplace collegiality and leisure time out of work), (iv) needs for respectability (recognition and appreciation of internal and external employees), (v) needs for realization (realizing the needs of the organization), (vi) information needs (learning business and occupational skills), (vii) aesthetic needs (creativity at work, personal creativity). Zare, Haghgooyan and Asl (2012) reported that QWL can be explained by four factors as a result of their study to define the dimensions of quality of work life: (i) Work-life balance (fair 
working hours, work-life atmosphere, opportunity to attend religious ceremonies, ergonomics, no physical and mental harm, the distance between work and home). (ii) Social factors (the importance of work in society, social integration in the organization, social networks in the workplace, respect for employees, sense of self-esteem in the organization, good colleagues. (iii) Economic factors (salary, health care, insurance, pension, occupational safety). (iv) Content of the work (teamwork, independence, meaningful work, rich and demanding work, a feeling of ownership at work, necessity of creativity at work, opportunity for professional development).

Sirgy et al. (2001) classified QWL in two primary categories: low-grade quality of work life consisted of health/safety needs and economic/family needs and high-level quality of work life composed of social needs, reputation needs, self-realization needs, information needs, and aesthetic needs. According to Nadler and Lawler (1983), the types of QWL activities are participatory problem solving, restructuring the business, rewarding innovation and improving the business environment. Measures of quality of work life include increased worker participation, the increment of participation and strength, increased emphasis on employee skills development, increased autonomy for action and decision-making at the worker level, and reduced status distinctions among levels of hierarchy. Various researchers have used distinct components to reveal the quality of work life of employees. Bora (2017) revealed that the quality of academic work life consists of 18 components. These; adequacy of resources, adequate and fair payment, work autonomy, emotional intelligence, employee attitude, facilities, difficulties and responsibility of the work, job satisfaction, work security, leadership styles, nature of work, occupational stress, growth and development opportunities, organizational commitment, organizational culture, relationship and cooperation, education and development and working environment. In addition, to improve quality of work life following aspects must be ensured: Fair and sufficient payment, work safety and healthy working conditions, development of human skills, social integration for organizational commitment, coping with work-related stress, providing occupational development opportunities, providing work-family balance, support of administrators, following the rules and regulations in the work environment, and work security and social justice (Fernandes, Martins, Caixeta, \& Antonialli, 2017; Kösterelioğlu, 2011; quoted from Walton, 1975, Barzoki \& Sarand, 2015).

A successful organization considers the quality of work life of employees as a strategy to provide a competitive advantage. Because the quality of work life has benefits to both organizations and employees (Kaur, 2016). In general terms, the key purpose of an effective quality of work life is to improve working conditions, to influence positively and to increase the efficiency of employees and the organization and the quality of services and products (Ashraf, 2009; Bora, 2017; Danna \& Griffim, 1999; Demir, 2011; Dolan \& Lingham, 2012; Gibson, Ivancevich, Donnelly, \& Konopaske, 1991; Lau, 2000). Studies have substantiated the importance of QWL in achieving positive workplace behavior and attitudes such as job satisfaction, organizational commitment, diminishing absenteeism and stress levels, employee welfare, participation and even improved performance (Baba \& Jamal, 1991; Bora, 2017). In detail, the quality of work life is ameliorated to increase these complementary factors: Individual effectivity, accountability, organizational and occupational commitment, to make effective teamwork and communicate, to reduce organizational stress, to improve relationships within and outside the organization, to enhance employee morale and safe working conditions, to improve human resources, to enhance employee satisfaction, workplace satisfaction, and learning in the workplace, to better manage ongoing change and transition, to participate in management at all levels of the organization, to improve the physical and psychological health of employees and to develop a positive organizational image (Kaur, 2016). In light of the literature given above, it can be stated that the concept of quality of work life is a multidimensional concept, therefore, it is difficult and differs to define and measure. 
Quality of work life refers to the legal, physical, material, psychological, behavioral and emotional environment and opportunities offered to employees. With this environment and opportunities, it is aimed to increase employee productivity and thus to achieve positive results on organizational outputs. In this sense, the high/low quality of work life delivers many positive/negative results in terms of employees and organizational aspects. For example, when the quality of work life is high; teachers, academicians and people working in different organizations were found to perform higher performance (Ahmadian, Vafaeian, \& Farshbaf, 2015; Arslan, 2018; Gayathiri \& Ramakrishnan, 2013; Ghasemizad, Zadeh, \& Bagheri, 2012; Islam \& Siengthai, 2009; Kheirandish, 2009; Lau, \& May, 1998; Lau, 2000; Layer, Karwowski, \& Furr, 2009; Shoaf, Genaidy, Karwowski, \& Huang, 2004; Yılmaz, 2016). In addition, it has been determined that the high quality of work life increases peer and parent support, professional commitment, intention to remain, job satisfaction and motivation (Aba, 2009; Akar, 2018a; Azadehdel, \& Chooran, 2015; Bhatnagar \& Soni, 2015; Bhavani \& Jegadeeshwaran, 2014; Bolduc, 2001; Darabi, Mehdizadeh, Arefi, \& Ghasemi, 2013; Demir, 2011; Erat, 2010; Fatehi, Karimi, Pour, Pour, \& Azizi, 2015; Geisler, Berthelsen, \& Muhonen, 2019; Ghasemizad, Zadeh , \& Bagheri, 2012; Hasanati, 2018; Heidarie, Askary, Saedi, \& Gorjian, 2012; Hong, Tan, \& Bujang, 2010; Kermansaravi, Navidian, Rigi, \& Yaghoubinia, 2015; Linares, 2011; Maryniak, 2018; Mehta \& Mehta, 2015; Mhimd İbrahim, 2017; Muindi, 2015; Nimalathasan \& Ather, 2010; Pour, Rahmani, \& Qureshi, 2014; Stephen \& Dhanpal, 2012; Yalçın, Yıldırım, \& Akan, 2016). At the same time, it is determined the high quality of work life improves positive psychological capital level, organizational justice, organizational health, work, and emotional commitment, organizational citizenship (Akar, 2018b; Barzoki \& Sarand, 2015; Demir, 2019; Heidarie, Askary, Saedi, \& Gorjian, 2012; Hong, Tan, \& Bujang, 2010; Shoaf, Genaidy, Karwowski, \& Huang, 2004). In case of poor quality of work life, role conflict, employee intention to quit, burnout, alienation to organization, absenteeism and stress levels increase (Akar, 2018b; Altay \& Turunç, 2018; Başol, Sağlam, \& Çakır, 2018; Bolduç, 2001; Demir, 2011; Hong, Tan, \& Bujang, 2010; Kösterelioglu, 2011; Linares, 2011; Yilmaz, 2016). On this account, the quality of work life fosters an environment for the formation of an effective and efficient organization and increases the satisfaction of employees (Akar \& Üstüner, 2017; Gadon, 1984). In summary, it is understood from the results of this research that the quality of work life is crucially important for both organization and employee. In addition, it is recommended employees' commitment to their organizations should be examined while investigating the quality of work life (Sarl, 2007).

Blau (1987) stated organizational commitment is a concept that states that an individual wants to maintain the membership of an organization. According to O'Reilly and Chatman (1986), organizational commitment represents the psychological commitment of employees to their organization. According to Meyer and Allen (1991), this psychological state has a determining effect on the relationship between the employee and the organization and the decision of the employee to stay or leave the organization. In the same way, Meyer, Allen, and Smith (1993) defined organizational commitment as a psychological commitment that characterizes the employee's relationship with the organization and will influence the decision to maintain or terminate membership in the organization. According to Wiener (1982), in order to comprehend the power of commitment to an organization, an individual must make a sacrifice, be committed to the organization continuously and show how mentally connected he is with the organization. However, Katz and Kahn (1977) stated that the primary factor that constitutes organizational commitment stems from the awards that the members will receive while fulfilling their obligations within the organization. In various studies, a significant relationship is ascertained among organizational commitment and occupational commitment and development, work security, gaining autonomy, career opportunity, task compliance, turnover intentions, job satisfaction, leadership styles, students' educational performance and academic successes, job satisfaction, and occupational self-image (Aharon, Madjar, \& Kagan, 2019; Haftkhavani, 
Faghiharam, \& Araghieh, 2012; Kim \& Mueller, 2011; Linares, 2011; Parasız, Koç, Ilgar, \& Şahin, 2017; Yılmaz \& Kılıç, 2017).

Allen and Meyer (1990) conceptualized and measured organizational commitment in various ways. The multi-dimensional organizational commitment model developed by Allen and Meyer is generally accepted. They determined individuals are connected to organizations in three different ways. These; affective commitment, normative commitment and continuance commitment (Meyer \& Allen, 1991). Meyer and Allen (1991) suggest commitment is a psychological condition that demonstrates a kind of desire, needs and a necessity for the individual to work in the organization. The affective component of the organizational commitment suggested by the model expresses the emotional commitment and participation of employees to the organization (Allen \& Meyer, 1990). Affective commitment is defined as a strong and positive attitude towards the organization (Brown, 1996). Emotionally strong employees want to stay in the organization and continue to work (Meyer \& Allen, 1991).

Continuance commitment refers to commitment based on the costs associated with an employee leaving the organization (Allen \& Meyer, 1990). Continuance commitment means that the individual remains in the organization as a need component of the model or not (Meyer \& Allen, 1991). Kaya and Selçuk (2007) the factors affecting the continuance commitment; the reasons for such reasons as the cost of the individual leaving the work would be high and not being able to adapt to another work environment, being deprived of compensation in the workplace, being unemployed, and financial losses. Normative commitment, as the last component of the model, expresses the obligation of employees to remain in the organization (Allen \& Meyer, 1990). Normative commitment is the commitment that an individual must remain in the organization, probably because of an "internal moral obligation". Employees with high normative commitment think they should stay in the organization. Thus, employees need to stay in their organizations with a strong sense of normative commitment (Meyer \& Allen, 1991).

When the literature is examined, there are many studies that reveal that there is a significant relationship between the quality work of life and organizational commitment of administrators and employees in different fields of study such as health, finance, education and military, and that quality of work life strongly influences/predicts organizational commitment (Aharon, Madjar, \& Kagan, 2019; Ahmadian, Vafaeian, \& Farshbaf, 2015; Akar, 2018a; Altay \& Turunc, 2018; Barzoki \& Sarand, 2015; Daud, 2010a, 2010b; Daud, 2012; Daud, Yaakob, \& Ghazali, 2015; Demir, 2016; Erdem, 2010; Farid, Izadi, Ismail, \& Alipour, 2015; Heidarie, Askary, Saedi, \& Gorjian, 2012; Hong, Tan, \& Bujang, 2010; Sevgin, 2019; Saleem, 2017; Taşdemir Afşar, 2014; Yalcin \& Akan, 2016). However, it is seen that the studies comparing the effect of quality of work life on administrators' and teachers' commitment to school/organization are limited. In this context, the need to compare the effect of quality of work life on teachers' commitment to school emerged. The fact that - administrators and teachers are connected to school and work, satisfying their work, coping with stress and burnout, establishing strong effective relations with students, parents, and teachers, and in short, having a high IQ can be considered as one of the main factors in the success of schools (Erdem, 2010). It can be said that teachers and - administrators with high quality of work life will increase their commitment and performance and contribute to the achievements and successes of the school. In addition, identifying the factors that affect the commitment of administrators and teachers to the organization can provide an idea in the solution of the innovations and reforms that are aimed to be realized at the school level and the problems that arise in the school. The aim of this study is to compare the impact of the quality of work life on the organizational commitment of teachers and administrators. In accordance with this purpose; (i) Does the quality of work life and organizational commitment levels differ significantly between administrators and teachers? (ii) Is there a significant relationship between quality of work life and teachers 'and administrators' commitment to school? (iii) Does the quality of work life predict teachers 'and school administrators' commitment to school at different levels? 


\section{METHOD}

\section{Research Design}

In this research, because it was aimed to compare the effect of quality of work life on the organizational commitment of administrators and teachers, the predictive research design, one of the quantitative research predictive research design, was used. The predictive research design is a research design that is designed to predict future behaviors and determine the predictors of outcome (Creswell, 2017). In other words, it is a research design conducted to determine the variables that predict the dependent variable.

\section{Population and Sample}

The population of the study consists of a total of 6.741 teachers (including school principals and assistant principals) working in public schools (excluding kindergartens) in Tuzla (2907) and Sultanbeyli (3834) districts of Istanbul during the 2018-2019 and 2019-2020 academic years. The sample of the study consisted of 782 teachers and administrators. A cluster sampling method was used to involve teachers from each school level.

Table 1. Frequency and percentage distributions of demographic characteristics of the sample group

\begin{tabular}{llll}
\hline & Gruplar & $\boldsymbol{n}$ & $\boldsymbol{\%}$ \\
\hline \multirow{2}{*}{ Gender } & Female & 420 & 53,7 \\
\cline { 2 - 4 } Level of Education & Male & 362 & 46,3 \\
\hline \multirow{5}{*}{ Seniority } & Bachelors & 651 & 83,2 \\
\cline { 2 - 4 } & Postgraduate & 131 & 16,8 \\
\hline \multirow{3}{*}{ School Level } & 5 years and under & 145 & 18,5 \\
\cline { 2 - 4 } & 6-10 years & 216 & 27,6 \\
\cline { 2 - 4 } & 11-15 years & 139 & 17,8 \\
\cline { 2 - 4 } & 16-20 years & 124 & 15,9 \\
\cline { 2 - 4 } Duty & 21 years and above & 158 & 20,2 \\
\cline { 2 - 4 } & Primary & 230 & 39,4 \\
\cline { 2 - 4 } & Secondary & 305 & 75,6 \\
\hline Tigh School & Teacher & 591 & 24,4 \\
\cline { 2 - 4 } & $\begin{array}{l}\text { Administrators } \\
\text { (principals=76; asistant } \\
\text { principals= 112) }\end{array}$ & 191 & $\mathbf{1 0 0 . 0}$ \\
\hline
\end{tabular}

When Table 1 is examined, a total of 782 administrators (principals and assistant principals) and teachers, 420 females and 362 male subjects participated in the study. 651 of the administrators and teachers have a bachelor's degree and 131 of them have postgraduate degrees. Participants have seniority ranging from seniority of 5 years and under to seniority of 21 years and above. 230 of them worked in primary school, 305 in secondary and 247 worked in high school. It is understood that 191 are administrators and 591 are teachers. The participant administrators are 79 school principals and 112 assistant principals.

\section{Data Collection Tools}

In this study, the data collection tool consists of three parts. In the first part, the "Information Form", which includes information on gender, graduation status, professional seniority, type of school and duty of the administrators and teachers is given. Quality of Work Life Scale and Organizational Commitment Scale was chosen because their validity and reliability analysis and studies are up to date.

Quality of Work Life Scale: Quality of Work Life Scale was developed by Van Laar, Edwards and Easton (2007). It was adapted to Turkish by Akar and Üstüner (2017). The Quality of Work 
Life Scale was rated as a 5-point Likert type. The scale consists of 23 items and 6 sub-dimensions (work and career satisfaction, general well-being, family-work life balance, the stress in work life, controlling work and working conditions). The items in the scale; "I feel good (happy and peaceful)." and "The working conditions at the school where I work are quite satisfactory." for example. The lowest 23 points and the highest 115 points can be obtained from the scale. In their study, Akar and Üstüner (2019) reported the reliability coefficient of the scale as 0.93. In this study, the reliability coefficient of the scale was calculated as 0.892 .

Organizational Commitment Scale: For the aim of measuring teachers' and administrators' organizational commitment levels, the "Organizational Commitment Scale" developed by Üstüner (2009) was used. The scale is a 5-point Liker-type scale consisting of 17 items and one dimension. The lowest 17 points and the highest 85 points can be obtained from the scale. The items in the scale; "I feel connected here because I think I was considered and taken into account in this school." and "I feel completely part of this school." for example. Üstüner (2009) determined the reliability coefficient of the scale as 0.96 . In this study, the reliability coefficient of the scale was calculated as 0.965 .

The study was conducted in accordance with the rules of research and publication ethics. Ethics Committee Permission was obtained to conduct the study and collect data.

\section{Data Analysis}

The scale was distributed to 1000 participants, but there was a return from 820 participants. The return rate of the scales is $82 \%$. Since the scales of 38 participants from 820 participants were missing or incorrect, they were not included in the analysis. Findings obtained from this study were analyzed by the SPSS program. Normality values and reliability coefficients were calculated to determine whether the data would be analyzed according to the purpose of the study.

Table 2. Descriptive values of scales

\begin{tabular}{lcccccc}
\hline Variables & N & Mean & SD & Skewness & Kurtosis & $\boldsymbol{a}$ \\
\hline $\begin{array}{l}\text { Organizational } \\
\text { Commitment }\end{array}$ & 782 & 3,7925 &, 88094 &,- 725 &, 122 & .965 \\
\hline Quality of Work Life & 782 & 3,6956 & .59781 &,- 290 &,- 134 & .892 \\
\hline
\end{tabular}

When Table 2 is examined, it is seen that the data obtained from the organizational commitment $(M=3.79 ; \mathrm{SD}=.88)$ and quality of work life $(\mathrm{M}=3.69 ; \mathrm{SD}=59)$ scales remained between -1 and +1 and showed normal distribution. In addition, organizational commitment $(a=.96)$ and quality of work life $(a=.89)$ scales were found to be reliable.

\section{RESULTS}

Table 3 shows the independent t-test results to determine the meaningful differences between teachers' quality of work life and school commitment.

Table 3. T-test of QWL and OC scores according to gender

\begin{tabular}{|c|c|c|c|c|c|c|c|}
\hline Variables & Groups & $\mathbf{n}$ & Mean & SD & $t$ & $d f$ & $p$ \\
\hline \multirow{2}{*}{$\begin{array}{l}\text { Quality of } \\
\text { Work Life }\end{array}$} & Teacher & 591 & 3,610 & ,593 & \multirow{2}{*}{$-7,274$} & \multirow{2}{*}{780} & \multirow{2}{*}{,000 } \\
\hline & Administrator & 191 & 3,960 &, 529 & & & \\
\hline \multirow{2}{*}{$\begin{array}{l}\text { Organizational } \\
\text { Commitment }\end{array}$} & Teacher & 591 & 3,618 & 882 & \multirow{2}{*}{$-10,354$} & \multirow{2}{*}{780} & \multirow{2}{*}{,000 } \\
\hline & Administrator & 191 & 4,330 & 622 & & & \\
\hline
\end{tabular}

When Table 3 was examined, it was found that participants' perceptions of quality of work life $\left(\mathrm{t}_{[780]}=-7.274 ; \mathrm{p}<.01\right)$ and organizational commitment showed a significant difference to their tasks $\left(\mathrm{t}_{[780]}=-10.354 ; \mathrm{p}<.01\right)$. School administrators' perceptions of quality of work life $(\mathrm{M}=3.96)$ and organizational commitment $(\mathrm{M}=3.61)$ are higher than teachers' perception of the quality of work life $(\mathrm{M}=3.61)$ and organizational commitment $(\mathrm{M}=3.61)$. 
The results of the correlation analysis conducted to determine the relationship between teachers' and administrators" perception of the quality of work life and organizational commitment are given in Table 4.

Table 4. Results of correlation analysis between $Q W L$ and $O C$

\begin{tabular}{llcc}
\hline Groups & Variables & \multicolumn{2}{c}{ Organizational Commitment } \\
\hline \multirow{2}{*}{ Teachers } & \multirow{2}{*}{ Quality of Work Life } & $\mathrm{r}$ & $.723^{* *}$ \\
\cline { 3 - 4 } Administrators & Quality of Work Life & $\mathrm{p}$ & .000 \\
\cline { 3 - 4 } & & $\mathrm{r}$ & $.576^{* *}$ \\
\cline { 3 - 4 } & & $\mathrm{p}$ & .000 \\
\hline
\end{tabular}

According to the correlation analysis given in Table 4, there was a "high" and positive $(\mathrm{r}=.723 ; \mathrm{p}<01)$ relationship between the teachers' perceptions of OC and the QWL levels; It is seen that there is a "moderate and positive" relationship ( $\mathrm{r}=.576$; $\mathrm{p}<01)$ between the QWL perceptions of the administrators and the OC levels.

The results obtained from the regression analysis conducted to compare the levels of quality of work life, organizational commitment levels of administrators and teachers are given in Table 5.

Table 5. The results of the regression analysis of the level of predicting organizational commitment of teachers' perceptions of quality of work life

\begin{tabular}{|c|c|c|c|c|c|c|c|}
\hline Group & $\begin{array}{l}\text { Independent } \\
\text { Variable }\end{array}$ & $\begin{array}{l}\text { Dependent } \\
\text { Variable }\end{array}$ & B & $\begin{array}{l}\text { Std. } \\
\text { Error }\end{array}$ & $(\beta)$ & $\mathbf{t}$ & $\mathbf{p}$ \\
\hline \multirow{2}{*}{ Teachers } & \multirow{2}{*}{$\begin{array}{l}\text { Quality of } \\
\text { Work Life }\end{array}$} & \multirow{2}{*}{$\begin{array}{l}\text { Organizational } \\
\text { Commitment }\end{array}$} &,- 261 & ,155 & & $-1,690$ & ,091 \\
\hline & & & 1,075 & ,042 & ,723 & 25,434 & ,000 \\
\hline \multicolumn{8}{|c|}{$\mathrm{R}=.723 ; \mathrm{R}^{2}=.523 ; \mathrm{F}=646.868, \mathrm{p}<.01$} \\
\hline \multirow{2}{*}{ Administrators } & \multirow{2}{*}{$\begin{array}{l}\text { Quality of } \\
\text { Work Life }\end{array}$} & \multirow{2}{*}{$\begin{array}{l}\text { Organizational } \\
\text { Commitment }\end{array}$} & 1,651 & 279 & & 5,908 & ,000 \\
\hline & & & 677 & 070 & ,576 & 9,675 & ,000 \\
\hline
\end{tabular}

$\mathrm{R}=.576 ; \mathrm{R}^{2}=.331, \mathrm{~F}=24.398, \mathrm{p}<.01$

When Table 5 is examined, it is seen that the quality of work life significantly predicts the organizational commitment of teachers $\left(r^{2}=.723 ; p<.001\right)$. In other words, $52 \%$ of the total variance in teachers' organizational commitment level is explained by the quality of work life $\left(\beta=.723 ; \mathrm{r}^{2}=.523 ; \mathrm{F}=646.868 ; \mathrm{p}<.01\right)$. It was also observed that the quality of work life significantly predicted organizational commitment levels of school administrators $\left(r^{2}=.576 ; p<.001\right)$. In other words, the quality of work life accounted for $33 \%$ of the total variance in organizational commitment levels of administrators $\left(\beta=.576 ; r^{2}=.331 ; F=24.398 ; p<.01\right)$.

\section{CONCLUSION and DISCUSSION}

According to the first result of the present study, perceptions of administrators and teachers about the quality of work life and organizational commitment differ significantly. Administrators' perceptions of quality of work life and organizational commitment are higher than teachers. Although there are a limited number of studies comparing the perceptions of administrators and teachers to the quality of work life in the literature, Shobe (1983) tried determining the QWL perceptions of primary school principals and teachers working in five states (Illinois, Indiana, Kentucky, Michigan, and Ohio) in the USA. As a result of the research, QWL perceptions of primary school principals were determined to be relatively higher than teachers. 
Moreover, Hart (1992) demonstrated that school principals' and teachers' organizational commitment was higher than the teachers' organizational commitment. According to the findings, it can be stated that school administrators are more attached to the school they work in compared to the teachers and they perceive the work life elements in the school they manage more positively. School administrators may not identify their deficiencies by embracing their schools more.

According to another notable result of the study, it was remarked that there is a significant relationship between the QWL and OC perceptions of teachers and administrators. However, the relationship between administrators' perceptions of quality of work life and organizational commitment levels is lower than the relationship between teachers' perceptions of quality of work life and organizational commitment levels. In other words, the relationship between teachers' perception of the quality of work life and organizational commitment levels is higher than the relationship between administrators' perceptions of quality of work life and organizational commitment levels. According to regression analysis based on this relationship, teachers 'and administrators' perceptions of quality of work life affect their organizational commitment levels at varying levels, positively and strongly. However, the quality of work life affects teachers 'organizational commitment more than administrators' organizational commitment. The findings once again revealed the necessity and importance of quality of work life for organizational commitment. However, although there is no study comparing the effect of administrators' and employees' perception of the quality of work life on organizational commitment, it is consistent with the results of other studies in the literature in general. In the researches, it was determined that perceptions of the quality of work life (fair and sufficient payment, legality, social dependence, talent development, environmental security, social cohesion) and organizational commitment of the employees in the service and production sector are related/related. Perceptions quality of work life of managers and workers, teachers, soldiers, nurses and doctors, flight attendants, social workers, and other workers in organizations serving or producing in education (k-12 and university), military, health, aviation, tourism, social and commercial fields significantly influence/predict organizational commitment in an important, positive and powerful way (Ahmadian, Vafaeian, \& Farshbaf, 2015; Altay, \& Turunç, 2018; Barzoki \& Sarand, 2015; Buffardi, Baughman, \& Morse, 2004; Dudley, 2015; Geisler, Berthelsen, \& Muhonen, 2019; Ghasemizad, Zadeh, \& Bagheri, 2012; Karaaslan \& Aslan, 2019; Hong, Tan, \& Bujang, 2010; Karaköse \& Bozgeyikli, 2012; Shahrashob, 2006; Taşdan, 2008; Taşdemir Afşar, 2014; Yalçın, 2014; Yalçın \& Akan, 2016; Yalçın, Yıldırım, \& Akan, 2016; Walter, 2017). Especially in the meta-analysis study conducted by Akar (2018a), it was discovered that employees' perceptions of quality of work life strongly affected their organizational commitment. In other words, when teachers 'and administrators' career satisfaction, general well-being and working conditions are improved, they can control the work, the stress in work life decreases and they achieve family-work balance, their organizational commitment increases. As a result, organizational commitment of teachers and administrators increases when their career satisfaction, general well-being and working conditions in the organization are improved, when they can control the work, the stress in work life is reduced, and when they achieve family-work balance. However, it can be concluded that school administrators were affected the most from these situations. In other words, organizational commitment of administrators and teachers increases when safe and healthy working conditions, self-realization and professional development opportunities are provided, fair course and payment distribution is made, a strong culture and a positive climate are created, achievements are appreciated, and cooperation is established among the school community. However, the equivalent conditions of the quality of work life do not have the same effect on school administrators and teachers. The key reason for this is that school administrators may perceive the factors related to the quality of work life more positively than the teachers and reflect them on their organizational commitment. 
In addition, when considered from a different perspective, teachers' organizational commitment may be lower than school administrators' because teachers either evaluate the quality of work life more objectively than school administrators or they are unsatisfied with the quality of work life offered at school. In addition, quality of work life influences organizational commitment, and quality of work life is a mediating variable that reduces the negative impact of organizational cynicism on organizational commitment (Yasin \& Khalid, 2015) and weakens the negative impact of wages on employee performance (Gunawan \& Amalia, 2015), increases employee productivity (Ghasemizad, Zadeh, \& Bagheri, 2012), and reduce workers' antiproduction and harmful behaviors (Masoomzadeh, Feizi, and Alipour, 2013). In addition to these findings, it has been found that activities aimed at improving the quality of work life led to improvements in employee productivity and absenteeism rates (Kanten, \& Sadullah, 2012; Marks, Mirvis, Hackett, \& Grady, 1986), increased organizational effectiveness (Donaldson, Sussman, Dent, Severson, \& Stoddard, 1999), and by negatively affecting the intention to leave and alienation, it reduces the intention and alienation of the employee (Altay \& Turunç, 2018; Genç, 2015; Güçlü, 2014; Kösterelioğlu, 2011). In summary, employees' organizational commitment increases only when their quality of work life is improved (Fields \& Thacker, 1992; Walter, 2017). When the findings of this research and other research findings in the literature are evaluated together, it can be concluded that, besides the strong effect of the quality of work life on organizational commitment, it is a substantial factor in almost all dimensions of organizational life and outcomes.

Schools are expected to play a major role in the construction of the global order and in the cognitive, affective, behavioral and social education, raising, and development of individuals who will define the future. The fulfillment of this task, responsibility, goals, and roles expected from schools depends largely on the leadership and talented teachers. It would not be incorrect to say that providing quality education to administrators and teachers depends on the quality of work life offered to them. Because the quality of work life positively and significantly affects the organizational commitment, job satisfaction and performance of administrators, teachers, and other employees, it can contribute positively to school effectiveness, innovation capacity, efficiency, change, development, competitiveness, performance and other outputs. These results can be considered as evidence of increasing school commitment and willingness to work in schools if administrators and teachers have a high quality of work life, and based on all these results, it can be said that when the quality of work life in schools is improved, the commitment of teachers and administrators to the school they work in will increase.

Although the quality of work life delivers a direct impact on administrators, teachers and other employees in general, it also indirectly affects the quality of education provided to children in schools. In this sense, quality of work life can be considered as a tool to improve the quality of education.

The literature and the results of this research are expected to show a road map to education managers and decision-makers in education to improve the performance and success of teachers and administrators. These results indicate that quality of work life is a factor that can change the quality and degree of organizational commitment and that changes in quality of work life and organizational commitment may be associated with significant attitudes, behaviors, and outcomes on the organization and the employee.

Besides, there are some significant results of this study for both practical and future researches. Most importantly, producing a qualified education in the literature and the schools including these research results shows that the quality of work life of administrators and teachers is an important factor in organizational commitment. Therefore, addressing the quality of work life in schools is of immense importance for the performance of administrators and teachers in the education system. It is advisable to improve the working conditions of the administrators and the teachers who produce the education service with the activities and regulations stated in the 
literature in order to provide the education accepted to be the guarantee of our future at the desired level at the individual, social and national level (Bora, 2017; Fernandes, Martins, Caixeta, and Antonialli, 2017; Kaur, 2016; Kösterelioğlu, 2011; Nadler \& Lawler, 1983; Sirgy, Efraty, Siegel, \& Lee, 2001; Van Laar, Edwards, \& Easton, 2007; Walton, 1973; Walton, 1975 act., Barzoki \& Sarand, 2015; Zare, Haghgooyan and Asl, 2012). In order to achieve this, senior managers and policymakers need to analyze the factors that encourage or prevent the quality education and training of administrators and teachers and make applications according to these factors. In the schools where teachers and school administrators work effectively to fulfill the goals and objectives of the school, a physically and psychologically healthy environment can be provided in qualifying conditions, the teaching and management profession can be strengthened with legal regulations, fees can be improved with financial support, public spots can be made to increase social status. Since the quality of work life and organizational commitment are important factors in determining teachers 'and administrators' feelings, attitudes and behaviors towards the school, further comparative research on the quality of work life and organizational commitment may be suggested.

\section{REFERENCES}

Aba, G. (2009). İs yaşam kalitesi ve motivasyon ilişsisi: Sağlık sektöründe bir uygulama [The relationship between quality of work life and motivation: an application in the health sector] (Unpublished master thesis-Yayımlanmamış yüksek lisans tezi). Akdeniz Üniversitesi, Antalya.

Aharon, A. A., Madjar, B., \& Kagan, I. (2019). Organizational commitment and quality of life at work among public health nurses in Israel. Public Health Nursing.

Ahmadian, R., Vafaeian, M., \& Farshbaf, M. (2015). The relationship between the quality of working life with organizational commitment and employees' productivity of physical education faculties in the Islamic Azad University of Tehran. International Journal of Life Sciences, 9(4), 49-53.

Akar, H. (2018a). A meta-analytic study concerning the effect of educational stakeholders' perceptions of quality of work life on their job satisfaction and organizational commitment. International Online Journal of Educational Sciences, 10(3).

Akar, H. (2018b). The Relationships between quality of work life, school alienation, burnout, affective commitment, and organizational citizenship: A study on teachers. European Journal of Educational Research, 7(2), 169-180.

Akar, H. ve Üstüner, M. (2017). İş yaşam kalitesi ölçeğinin Türkçe uyarlaması: Geçerlik ve güvenirlik çalışması. [Turkish adaptation of quality of work life scale: Validity and reliability study]. İnönü Üniversitesi Eğitim Fakültesi Dergisi, 18(2), 159-176. DOI: 10.17679/inuefd.302675

Allen, N. J., \& Meyer, J. P. (1990). The measurement and antecedents of affective, continuance and normative commitment to the organization. Journal of Occupational Psychology, 63(1), 1-18.

Altay, M., \& Turunç, Ö. (2018). İş yükü, çalışma yaşam kalitesi ve işten ayrılma niyeti ilişkisi: lider-üye etkileşiminin ve örgütsel bağllığın aracllık rolü [Workload, quality of life and intention to quit: mediator role of leader-member interaction and organizational commitment]. Kafkas University. Faculty of Economics and Administrative Sciences. Journal, 9(17), 191-229.

Arslan, I. (2018). Sağlık çalışanlarında iş yaşam kalitesinin iș performansı üzerine etkisinde örgütsel desteğin aracllk rolü [The mediating role of organizational support in the impact of quality of work life on work performance in health care workers] (PhD. Dissertation-Doktora tezi). Okan Üniversitesi Sağllk Bilimleri Enstitüsü, İstanbul.

Ashraf, M. M. (2009). A study of job involvement and quality of work life in relation to need patterns of Government and Non-Government educational institutions. Retrieved from http://ir.inflibnet.ac.in:8080/ispui/bitstream/10603/177154/14/14 discussion.pdf on 28 November 2019.

Azadehdel, M. R., \& Chooran, B. S. (2015). Quality of work life and its role in job satisfaction of organizational managers: The Case of managers in Alborz Insurance Company's Branches. Cumhuriyet Üniversitesi Fen-Edebiyat Fakültesi Fen Bilimleri Dergisi, 36(3), 258-266.

Baba, V. V. \& Jamal, M. (1991). Routinization of job context and job content as related to employees' quality of working life: A study of Canadian nurses. Journal of Organizational Behavior, 12(5), 379-386.

Barzoki, A. S., \& Sarand, V. F. (2015). Investigating the relationship between organizational justice, organizational commitment and staff's quality of work life (Case study: Islamic Azad University 
employees Shabestar). International Journal of Academic Research in Economics and Management Sciences, 4(2), 34-44.

Başol, O., Sağlam, Y., \& Çakır, N. N. (2018). Engelli ve yaşlı bakım personelinin tükenmişlik seviyeleri ile çalışma yaşamı kalitesi algısı ilişkisi [The relationship between burnout levels of disabled and elderly care personnel and perception of quality of work life]. Toplum ve Sosyal Hizmet, 29(2), 7197.

Bhatnagar, T. \& Soni, H. (2015). Impact of quality of work life on job satisfaction of school teachers in Udaipur city, IOSR Journal of Business and Management, 17(3), 10-14.

Bhavani, M., \& Jegadeeshwaran, M. (2014). Job satisfaction and quality of work life-a a case study of women teachers in higher education. SDMIMD Journal of Management, 5(2), 1-12.

Blau, G. J., \& Boal, K. B. (1987). Conceptualizing how job involvement and organizational commitment affect turnover and absenteeism. Academy of Management Review, 12(2), 288-300.

Bolduc, R. R. (2001). An analysis of the relationship between quality of work life and motivation for correctional services officers in the Montreal area (Quebec) (Doctora tezi). McGill University, Montreal.

Bora, B. (2017). Quality of work life components: a liteatüre review in the academic sector. International Journal of Creative Research Thoughts (IJCRT), 5(4), 1470-1476.

Brown, R. B. (1996). Organizational commitment: Clarifying the concept and simplifying the existing construct typology. Journal of Vocational Behavior, 49(3), 30-252.

Buffardi, L., Baughman, K., \& Morse, K., (2004). Findings from the 2003 quality of work life, a survey of George Mason University Employees, Draft Report.

Chen, J. C., Silverthorne, C., \& Hung, J. Y. (2006). Organization communication, job stress, organizational commitment, and job performance of accounting professionals in Taiwan and America. Leadership \& organization Development journal, 27(4), 242-249.

Cohen, A. (2007). Dynamics between occupational and organizational commitment in the context of flexible labor markets: A review of the literature and suggestions for a future research agenda (ITBForschungsberichte, 26). Bremen: Universität Bremen, Institut Technik und Bildung (ITB). https://nbn-resolving.org/urn:nbn:de:0168- ssoar-410893

Cresweel, J. W. (2017). Nicel ve nitel Araştırmanın planlanması, yürütülmesi ve değerlendirilmesi [Quantitative and qualitative research planning, conducting and evaluation] (H. Ekși, Çev/Translated. Ed.). İstanbul: Edam.

Danna, K., and Griffin, R. W. (1999). Health and well-being in the workplace: A review and synthesis of the literature. Journal of Management, 25(3), 357-384.

Darabi, M., Mehdizadeh, A. H., Arefi, M., \& Ghasemi, A. A. (2013). Relationship between quality of work life and job satisfaction on school teachers in Kermanshah. Journal of Educational and Management Studies, 3(4), 508-513.

Daud, N. (2010a, November). Quality of work life and organizational commitment amongst academic staff: Empirical evidence from Malaysia. In 2010 International Conference on Education and Management Technology (pp. 271-275). IEEE.

Daud, N. (2010b). Investigating the relationship between quality of work life and organizational commitment amongst employees in Malaysian firms. International Journal of Business and Management, 5(10), 75.

Daud, N. (2012). The Influence of quality of work life on organizational commitment: A Study on academic staff in public institution of higher learning in Malaysia, International Conference on Innovation, Management and Technology Research (ICIMTR2012), Malacca, Malaysia: 21-22 May 2012.

Daud, N., Yaakob, Y., \& Ghazali, S. N. M (2015). Quality of work life and organizational commitment: empirical investigation among academics in public institution of higher learning. IJABER, 13(7), 6129-6146.

Davis, L. E. (1977). Enhancing the quality of working life: Developments in the United States. Int'l Lab. Rev., 116, 53.

Dehghan Nayeri, N., Salehi, T., \& Ali Asadi Noghabi, A. (2011). Quality of work life and productivity among Iranian nurses. Contemporary Nurse, 39(1), 106-118.

Demir, E. (2019). Öğretmenlerin iş yaşam kalitesi ile pozitif psikolojik sermaye düzeyleri arasındaki ilişkinin incelenmesi [Examination of the relationship between teachers' quality of work life and positive psychological capital levels] (Master thesis-Yüksek lisans tezi). İnönü Üniversitesi Eğitim Bilimleri Enstitüsü, Malatya.

Demir, M. (2011). İşgörenlerin çalışma yaşamı kalitesi algılamalarının işte kalma niyeti ve işe devamsızlık ile ilişkisi [The relationship between employees' perception of quality of work life and intention to stay and absenteeism]. Ege Akademik Bakış Dergisi, 11(3), 453-464. 
Demir, T. (2016). Meslek lisesi öğretmenlerinin işyaşam kalitesine ilişkin algıları ile örgütsel bağlllık düzeyleri arasindaki ilişki [The relationship between vocational high school teachers' perception of quality of work life and organizational commitment levels] [Unpublished master thesis-Yayımlanmamış yüksek lisans tezi). İstanbul Sabahattin Zaim Üniversitesi, Sosyal Bilimler Enstitüsü, İstanbul.

Dolan, S., \& Lingham, T. (2012). Introduction to international organizational behavior. Logan: BookEducator.

Donaldson, S. I., Sussman, S., Dent, C. W., Severson, H. H., \& Stoddard, J. L. (1999). Health behavior, quality of work life, and organizational effectiveness in the lumber industry. Health Education \& Behavior, 26(4), 579-591.

Dudley, D. B. (2015). The influence of work-based factors, non-work life factors, and individual factors on the overall quality of working life of united states medical surgical registered nurses working in acute care hospitals (Doctoral dissertation). Louisiana State University, New Orleans, Louisiana.

Easton, S., \& Van Laar, D. (2013). QoWL (Quality of Working Life): What, how, and why? Psychology Research, 3(10), 596-605.

Easton, S., \& Van Laar, D. (2018). User manual for the work-related quality of life (WRQoL) scale: A measure of quality of working life. Portsmouth, UK: University of Portsmouth.

Erat, Ş. (2010). Hemşirelerin iş yaşam kalitesinin motivasyona etkisi bir uygulama [The effect of nurses' quality of work life on motivation] (Master thesis-Yüksek lisans tezi). Beykent University, Social Sciences Institute, İstanbul.

Erdem, M. (2010). Öğretmen algılarına göre liselerde iş yaşamı kalitesi ve örgütsel bağlılıkla ilişkisi. [According to the perceptions of teachers, the quality of work life in high schools and its relationship with organizational commitment]. Kuram ve Uygulamada Eğitim Yönetimi Dergisi, 16(4), 511-537.

Farid, H., Izadi, Z., Ismail, I. A., \& Alipour, F. (2015). Relationship between quality of work life and organizational commitment among lecturers in a Malaysian public research university. The Social Science Journal, 52(1), 54-61.

Fatehi, B., Karimi, A., Pour, E. G., Pour, K. A., \& Azizi, B. (2015). Impact of quality of work life on job satisfaction. International Journal of Sport Studies, 5(1), 79-86.

Fernandes, R. B., Martins, B. S., Caixeta, R. P., \& Antonialli, L. M. (2017). Quality of work life: An evaluation of Walton model with analysis of structural equations. Espacios, 38(03).

Fields, M. W., \& Thacker, J. W. (1992). Influence of quality of work life on company and union commitment. Academy of Management Journal, 35(2), 439-450.

Gadon, H. (1984). Making sense of quality of work life programs. Business Horizons, 27(1), 42-46.

Gayathiri, R., \& Ramakrishnan, L. (2013). Quality of work life-Linkage with job satisfaction and performance. International Journal of Business and Management Invention, 2(1), 1-8.

Geisler, M., Berthelsen, H., \& Muhonen, T. (2019). Retaining social workers: the role of quality of work and psychosocial safety climate for work engagement, job satisfaction, and organizational commitment. Human Service Organizations: Management, Leadership \& Governance, 43(1), 1-15.

Genç, E. (2015). İs yaşam kalitesi ve işe yabancılaşmanın işten ayrılma niyeti üzerine etkisi: Hizmet sektöründe bir uygulama [The effect of quality of work life and alienation to work on intention to quit: an application in the service sector] (Unpublished master thesis-Yayımlanmamış yüksek lisans tezi). Mustafa Kemal Üniversitesi, Sosyal Bilimler Enstitüsü, Hatay.

Ghasemizad, A., Zadeh, M. A., \& Bagheri, S. (2012). A study of the relationship between teachers and principals' spiritual leadership, quality of work life, job satisfaction and productivity. American Journal of Scientific Research, 49, 11-20.

Gibson, J. L., Ivancevich, J. M., Donnelly, J. H., \& Konopaske, R. (1991). Organizations: Behavior, structure, processes. Homewood, IL: Irwin.

Gunawan, H., \& Amalia, R. (2015). Wages and employees performance: The quality of work life as moderator. International Journal of Economics and Financial Issues, 5(1S), 349-353.

Güçlü, A. (2014). Cerrahi kliniklerinde çalışan hemşirelerin iş yaşam kalitesi ile işten ayrılma niyetleri arasındaki ilişki [Relationship between quality of work life and intention to leave of nurses working in surgical clinics] (PhD. Dissertation- Doktora tezi). Selçuk Üniversitesi Sağlık Bilimleri Enstitüsü).

Haftkhavani, Z. G., Faghiharam, B., \& Araghieh, A. (2012). Organizational commitment and academic performance (Case study: Students at secondary schools for girls). Procedia-Social and Behavioral Sciences, 69, 1529-1538.

Hart, D. R. (1992). Principals' organizational commitment, teachers' perceptions of principals' organizational commitment, and school environmental robustness (Doctoral dissertation). Pennsylvania State University, Pennsylvania. 
Hasanati, N. (2018, July). The role of work life quality towards teacher's professional commitment. In 2018 3rd International Conference on Education, Sports, Arts and Management Engineering (ICESAME 2018). Atlantis Press.

Heidarie, A., Askary, P., Saedi, S., \& Gorjian, B. (2012). Relationship between quality of work life, organizational health and commitment with job satisfaction. Life Science Journal, 9(3), 2300-2306.

Hong, K. S., Tan, K. W., \& Bujang, S. (2010). Relationships between work life quality of teachers with work commitment, stress and satisfaction: A study In Kuching, Sarawak, Malaysia. Jurnal Teknologi, $52(1), 1-15$.

Islam, M. Z., \& Siengthai, S. (2009, July). Quality of work life and organizational performance: Empirical evidence from Dhaka Export Processing Zone. In ILO Conference on Regulating for Decent Work, Geneva (pp. 1-19).

Jones, D. A., \& McIntosh, B. R. (2010). Organizational and occupational commitment in relation to bridge employment and retirement intentions. Journal of Vocational Behavior, 77(2), 290-303.

Kanten, S., \& Sadullah, O. (2012). An empirical research on relationship quality of work life and work engagement. Procedia-Social and Behavioral Sciences, 62, 360-366.

Karaaslan, A., \& Aslan, M. (2019). The Relationship Between the Quality of Work and Organizational Commitment of Prison Nurses. Journal of Nursing Research, 27(3), 25.

Karaköse, B., \& Bozgeyikli, H. (2012). Örgütsel bağllık ve çalıșma yașamı kalitesi arasındaki ilișki: Rehberlik araştırma merkezlerinde çalışan personel üzerine bir çalışma. [The relationship between organizational commitment and quality of work life: A study on staff working in guidance research centers]. Hak İs Uluslararası Emek ve Toplum Dergisi, 1(2), 164-180.

Katz, D., \& Kahn, R. L. (1977). Örgütlerin toplumsal psikolojisi [Sociological psychology of organizations] (H. Can and Y. Bayar, Çev./Trans.) Ankara: TODAİE-167.

Kaur, A. (2016). Quality of work life. International Journal of Engineering Science and Computing, 6(7), 83058311.

Kaya, N., \& Selçuk, S. (2007). Bireysel Başarı Güdüsü Organizasyonel Bağglılı̆̆ı Nasıl Etkiler? [How Does the Motivation of Individual Success Affect Organizational Commitment?] Doğuş Üniversitesi Dergisi 8(2), 175-190.

Kermansaravi, F., Navidian, A., Rigi, S. N., \& Yaghoubinia, F. (2015). The relationship between quality of work life and job satisfaction of faculty members in Zahedan University of Medical Sciences. Global Journal of Health Science, 7(2), 228.

Kheirandish, S.M. (2009). Relation between working life quality and performance of employees in Irankhodro Dizeli company. Master's thesis. Alame Tabatabaii University.

Kim, S. W., \& Mueller, C. W. (2011). Occupational and organizational commitment in different occupational contexts: The case of South Korea. Work and Occupations, 38(1), 3-36.

Kösterelioğlu, M. A. (2011). İlköğretim okulu öğretmenlerinin iş yaşam kalitesi ile ișe yabancılaşması arasindaki ilişki [The relationship between primary school teachers' quality of work life and alienation from work] (PhD. Dissertation-Doktora tezi). Abant İzzet Baysal Üniversitesi, Bolu.

Lau, R. S. (2000). Quality of work life and performance-An ad hoc investigation of two key elements in the service profit chain model. International journal of service industry management, 11(5), 422-437.

Lau, R. S., \& May, B. E. (1998). A win-win paradigm for quality of work life and business performance. Human Resource Development Quarterly, 9(3), 211-226.

Layer, J. K., Karwowski, W., \& Furr, A. (2009). The effect of cognitive demands and perceived quality of work life on human performance in manufacturing environments. International Journal of İndustrial Ergonomics, 39(2), 413-421.

Linares, P. J. P. (2011). Job satisfaction, organization commitment, occupational commitment, turnover intent and leadership style of Tissue bank employees (Doctoral dissertation). Capella University.

Marks, M. L., Mirvis, P. H., Hackett, E. J., \& Grady, J. F. (1986). Employee participation in a Quality Circle program: Impact on quality of work life, productivity, and absenteeism. Journal of Applied Psychology, 71(1), 61.

Maryniak, K. D. R. (2018). The correlation between peer support and quality of life of nurses (Doctoral dissertation), University of Phoenix.

Masoomzadeh, D., Feizi, M., \& Alipour, H. (2013). Surveying the relationship between quality of work Life components and counterproductive behavior in Ardabil province of mellat bank employees. Nigerian Chapter of Arabian Journal of Business and Management Review, 62(1087), 1-7.

Mehta, P. \& Mehta, B. (2015). Quality of work life and job satisfaction among govt. secondary school teachers of Haryana. Indian Journal of Health and Wellbeing, 6(3), 296-299.

Meyer, J. P., \& Allen, N. J. (1991). A Three-Component Conceptualization of Organizational Commitment. Human Resource Management Review, 1(1), 61-89. 
Meyer, J. P., Allen, N. J., \& Smith, C. A. (1993). Commitment to organizations and occupations: Extension and test of a three-component conceptualization. Journal of Applied Psychology, 78(4), 538.

Mhimd İbrahim, K. (2017). Sağlık çalışanlarının iş yaşam kalitesinin motivasyona etkisi: Gaziantep örneği [The effect of health care workers' quality of work life on motivation: Gaziantep case] (Master thesisYüksek lisans tezi). Kilis 7 Aralık Üniversitesi, Sosyal Bilimler Enstitüsü, Kilis.

Muindi, F. (2015). The Influence of Personality on the Relationship between Quality of Work Life and Job Satisfaction among Academic Staff in Kenyan Public Universities, British Journal of Economics, Management \& Trade, 15(2), 1-11.

Nadler, D. A., and Lawler, E. E. (1983). Quality of work life: perspectives and directions. Organizational Dynamics, 11(3), 20-30.

Nimalathasan, B., \& Ather, S. M. (2010). Quality of work life (QoWL) and job satisfaction (JS): A study of academic professionals of private Universities in Bangladesh. Annual Research Conference (ARC)2010, University of Jaffna, Jaffna, Sri Lanka.

O’Reilly, C. \& Chatman, J. (1986). Organizational commitment and psychological attachment: The effects of compliance, identification, and internalization on prosocial behavior. Journal of Applied Psychology, 71(3), 492-499.

Parasız, Ö., Koç, M., Ilgar, E., \& Şahin, M. Y. (2017). Relationship between organizational commitment and turnover intentions of academics. Journal of Human Sciences, 14(4), 4065-4076.

Pour, H. Z., Rahmani, M. N., \& Qureshi, A. (2014). The Study of Relationship between Quality of Work Life and Job Satisfaction of High School Teachers in Bandar Abbas. Am. J. Life. Sci. Res, 2(1), 118-124.

Saleem, R. (2017). Influence of quality of work life on organizational commitment among private school male-female teachers. Asia Pacific Journal of Research, 1(3), 101-108.

Saraji, G. N., \& Dargahi, H. (2006). Study of quality of work life (QWL). Iranian Journal of Publichealth, 35(4), 8-14.

Sarı, M. (2007). Demokratik değerlerin kazanımı sürecinde örtük program: Düşük ve yüksek okul yaşam kalitesi' sahip iki ilköğretim okulunda nitel bir çalışma [Implicit program in the process of the acquisition of democratic values: a qualitative study in two primary schools with low and high school life quality] (PhD. Dissertation-Doktora Tezi). Çukurova Üniversitesi, Sosyal Bilimler Enstitüsü, Adana.

Sevgin, M. N. (2019). Dönüşümcü ve etkileşimci liderlik davranışının iş yaşam kalitesi ve örgütsel bağlılık üzerine etkisi: Beş yıldızlı otel çalışanları üzerine bir araştırma [The effect of transformational and interactional leadership behavior on quality of work life and organizational commitment of work: A research on five-star hotel staff] (PhD. Dissertation-Doktora tezi). Mersin Üniversitesi, Sosyal Bilimleri Enstitüsü, Mersin.

Shahrashob, T. (2006). Relationship between Quality of Working Life and Organizational Commitment in GonbadeKavus city high school teachers (MA thesis). Allameh Tabatabai University, School of Psychology and Educational Sciences, Tehran.

Shoaf, C., Genaidy, A., Karwowski, W., \& Huang, S. H. (2004). Improving performance and quality of working life: A model for organizational health assessment in emerging enterprises. Human Factors and Ergonomics in Manufacturing \& Service Industries, 14(1), 81-95.

Shobe, R. E. (1983). Quality of work life as perceived by elementary school principals and by elementary school teachers (Ph.D. Thesis). Dissertation Abstracts International. Indiana State University, Indiana.

Sirgy, M. J., Efraty, D., Siegel, P., \& Lee, D. J. (2001). A new measure of quality of work life (QWL) based on need satisfaction and spillover theories. Social Indicators Research, 55(3), 241-302.

Stephen, A., \& Dhanpal, D. (2012). Quality of work life and its impact on job satisfaction in small scale industrial units: Employees perspectives. SDMIMD Journal of Management, 3(1), 11-24.

Subburethina Bharathi, P., Umaselvi, M., \& Senthil Kumar, N. (2010). Quality of work life: Perception of college teachers. Indian Journal of Commerce \& Management Studies, 2(1), 47-65.

Taşdemir Afşar, S. (2011). Effect of quality of work life on organizational commitment level: The quantitative research on academicians in State and Foundation Universities (Unpublished phd thesis). Hacettepe University, Ankara.

Taşdan, M. (2008). Study of quality of work life (QWL). Verimlilik Dergisi; Sayı: 1; 127-151.

Üstüner, M. (2009). Öğretmenler için Örgütsel Bağlılık Ölçeği: Geçerlik ve Güvenirlik Çalısması. [Organizational Commitment Scale for Teachers: Validity and Reliability Study]. Ínönü Üniversitesi Eğitim Fakültesi Dergisi, 10(1), 1-18.

Van Laar, D., Edwards, J. A., \& Easton, S. (2007). The work related quality of life scale for healthcare workers. Journal of Clinical Nursing. 3(60), 325-33. 
Walter, D. L. (2017). The relationship of quality of work-life and organizational commitment: A correlational study of flight attendants in the United States (Doctoral dissertation). Grand Canyon University, Phoenix, Arizona.

Wiener, Y. (1982). Commitment in organizations: Anormative view. Academy of Management Review, 7(3), 418-428.

Yalçın, S. (2014). Öğretmenlerin algılarına göre okul yöneticilerinin liderlik stilleri ile öğretmenlerin iş yaşam kalitesi ve örgütsel bağlllık düzeyleri arasındaki ilişkinin incelenmesi [Investigation of the relationship between school managers' leadership styles and teachers' quality of work life and organizational commitment according to teachers' perceptions] (PhD. Dissertation-Doktora tezi). Atatürk Üniversitesi Eğitim Bilimleri Enstitüsü, Erzurum.

Yalçın, S., \& Akan, D. (2016). Okul yöneticilerinin liderlik stilleri ile öğretmenlerin iş yaşam kalitesi ve örgütsel bağlılıkları arasındaki ilişkinin incelenmesi. [Examining the relationship between leadership styles of school managers' and teachers' quality of work life and organizational commitment]. Elektronik Sosyal Bilimler Dergisi, 15(59), 1138-1156.

Yalçın, S., Yıldırım, İ., \& Akan, D. (2016). Öğretmenlerin İş Yaşam Kaliteleri ile Örgütsel Bağlılıkları Arasındaki İlişkinin İncelenmesi. [Investigation of the Relationship Between Teachers' Quality of Work Life and Organizational Commitment]. Erzincan Üniversitesi Eğitim Fakültesi Dergisi, 18(1), 205-224.

Yasin, T., \& Khalid, S. (2015). Organizational cynicism, work related quality of life and organizational commitment in employees. Pakistan Journal of Commerce and Social Sciences (PJCSS), 9(2), 568582.

Yılmaz, A. (2016). Algılanan örgütsel destek ortamında iş stresi ve iş yaşam kalitesinin iş̧ performansı üzerine araștırılmasi: İstanbul'da bulunan beş yıldızlı otellerde çalışan aş̧̧ılar üzerine bir araștırma [Investigation of job stress and quality of work life on job performance in perceived organizational support environment: A research on chefs working in five star hotels in Istanbul] (PhD. DissertationDoktora Tezi). İstanbul Üniversitesi, Sosyal Bilimler Enstitüsü, İstanbul.

Yllmaz, E., \& Kilıç, Y. (2017). The Impact of organizational commitment on trainee teachers' job satisfaction. International Journal of Contemporary Educational Research, 4(1), 1-11.

Zare, H., Haghgooyan, Z. and Asl, Z. K. (2012). Determining and prioritizing the criteria and scales of quality of work life (QWF) by AHP Method. European Journal of Social Sciences, 27(3), 346-359.

Walton, R. E. (1973). Quality of working life: What is it. Sloan Management Review, 15(1), 11-21.

Walton, E. J. (1981). The comparison of measures of organization structure. Academy of Management Review, 6(1), 155-160. 